\title{
Efforts to increase beef cattle population with artificial insemination application in North Sulawesi, Indonesia
}

\author{
Derek Polakitan*, Hasrianti Silondae, and Ratri Retno Ifada \\ North Sulawesi Assessment Institute For Agricultural Technology (AIAT) \\ Kalasey Agriculture Campus Street, Manado, Indonesia, Postal Code: 95013
}

\begin{abstract}
The increasing population has a direct impact on the demand for animal food in the form of beef. The problem faced by beef cattle farmers in North Sulawesi province is low production and productivity. This study was aimed to determine the increase in beef cattle population in North Sulawesi Province with (AI) application. This study took place in 12 regencies/cities that carry out SIWAB programs in North Sulawesi Province, namely: Manado, Bitung, Tomohon, Kotamobagu, Minahasa, South Minahasa, Southeast Minahasa, North Minahasa, Bolaang Mongondow, North Bolaang Mongondow, South Bolaang Mongondow and East Bolaang Mogondow. This study is a case study using descriptive methods. Online data tracking techniques in stages from inseminator in the field, district, and provincial data officers. Data analysis consists of $\mathrm{S} / \mathrm{C}, \mathrm{CvR}, \mathrm{CR}$. The observations showed the number of ib application achievements 13682 acceptors, the number of orchards reached 11140 parents and the birth rate reached 8138 heads S/ C value 1.22 , CvR 73\%, CR $81.4 \%$. Conclusion The success of artificial insemination application on people's farms in North Sulawesi Province can be measured from the value of S / C 1.22, CvR 73\%, CR $81.4 \%$, and the increase in the population as much as 8138 heads.
\end{abstract}

\section{Introduction}

The fulfillment of national scale meat makes the government must import beef both frozen meat and in the form of beef will be quite large [1]. This situation is an opportunity for the people of North Sulawesi to develop a beef cattle farming business. The classic problem of people's livestock business in North Sulawesi Province is low productivity caused by rough maintenance management. The feed provided has not met the standards, has not handled the health of livestock optimally and the mating system is still original and has not done the selection precisely as a result of which farmers have difficulty getting cattle will be fattened. According to [2], emphasizing the quality and availability of livestock seedlings is very decisive in accelerating the increase in the population and supply of beef in the market. [3] explained that so far the obstacles in spurring the increase in beef cattle population are constrained by the availability of the number of seedling cows.

* Corresponding author: polakitandj@gmail.com 
The increase in the population in line with the increase in welfare and income of people in a region that encourages increased awareness of animal protein consumption. Nuryadi [4] stated that public awareness of the importance of consuming animal protein will further encourage the demand for beef. The scarcity of beef in Indonesia occurs today with soaring prices. Demand for beef is higher than the production rate.

The ability to meet the needs of domestic beef has only reached $65 \%$, the rest is fulfilled by importing frozen meat $20 \%$ and $15 \%$ in the form of beef will be fattened. A common problem faced by domestic farmers is the low productivity and genetic quality of livestock [5].

Anticipating the increasing national meat needs to make breakthrough efforts to increase the population and productivity of beef cattle, including the use of artificial insemination technology. [6] stated that cross between various cattle nations to obtain good seed quality can be achieved with artificial insemination technology (IB). [7] explained artificial insemination is an effort to optimize the use of selected superior males in improving the genetic quality of livestock. Artificial insemination will be optimal if supported by good quality cement frozen cement and liquid cement [8].

Regulation of the Minister of Agriculture No: 48/Permentan/OT.010/12/2016 concerning Special efforts to accelerate the increase in the population of cattle and buffalo gestation. This program Upsus SIWAB is an effort by the government to accelerate to achieve selfsufficiency of beef in the fulfillment of foodstuffs of animal origin while improving the welfare of farmers. Strategies in achieving government beef self-sufficiency enact policies: 1) increase livestock productivity by spurring the application of artificial insemination (AI) followed by cattle fattening efforts, 2) control of productive sheifer slaughter, 3) handling of livestock health and control and eradication of disease, 4) fulfillment of forage for animal feed, 5) institutional development. The purpose of writing is to find out the increase in beef cattle population in North Sulawesi Province through artificial insemination (AI) application.

\section{Methodology}

\subsection{Time and location}

This research is a case study using a descriptive method, which is a method used to find out the description of one thing by describing it based on the data collected, analyzed, and concluded $[9,10]$. This assessment took place from January to December 2020 in 12 districts/cities implementing the SIWAB program in North Sulawesi Province.

The samples used were 13682 cows that were artificially inseminated from 12 regencies/cities, namely: Manado, Bitung, Tomohon, Kotamobagu, Minahasa, South Minahasa, Southeast Minahasa, North Minahasa, Bolaang Mongondow, North Bola ang Mongondow, Bolaang Mongondow. South and East Bolang Mongondow. The types of data used are primary data and secondary data. Primary data were obtained from inseminator officers and other officers in the field, including the number of IB applications, the number of IB pregnancy tests, the number of IB pregnant mothers, and the number of IB births. Secondary data were obtained from BPS and reports on the results of previous studies. Online data retrieval techniques in stages from inseminators in the field to district recorders continue to provincial recorders through WAG.

The observed variables are 1). Service per conception $(\mathrm{S} / \mathrm{C})$ is the number of IB services for a parent to become pregnant. 2) Conception Rate (CR) is the percentage of pregnant mothers from the results of the first IB. 3) Calving Rate (CvR) is the percentage of births per number of mothers in IB. 


\subsection{Data analysis}

Data analysis was carried out by collecting data from primary and secondary data. Primary data were obtained from interviews with farmers and questionnaires, secondary data was obtained from monthly records of inseminators and then grouped. The data obtained were processed using descriptive analysis to obtain the Conception Rate Service per Conception and Calving rate.

Search result data is collected and analyzed using formulas :

$$
\begin{aligned}
& \text { Conception rate }=\frac{\text { Number of pregnant parent }}{\text { number of parent }} \times 100 \% \\
& \text { Calving rate }=\frac{\text { Number of births }}{\text { number of pregnant parent }} \quad x 100 \% \\
& \text { Service per conception }=\frac{\text { Number of parent in } I B}{\text { number of pregnant parent }}
\end{aligned}
$$

\section{Results and discussion}

\subsection{General condition of North Sulawesi}

The model of raising beef cattle in North Sulawesi Province is generally combined with agriculture. Cattle are used as labor and fed with agricultural waste. This model is mostly carried out in food crop centers such as the Minahasa community and some Bolaang Mongondow ones. In areas those have large uncultivated land, cattle are extensively reared with cattle grazing continuously. The model of intensive cattle rearing has begun to develop in the community, cattle have been housed with balanced feed, cultivate forage, have implemented health management, and treat livestock waste.

The livestock population is a portrait of livestock development performance in an area, livestock population density describes the suitability of this livestock with local agroecosystems, acceptance, and public interest in this livestock. Population dynamics of beef cattle development In North Sulawesi Province in 2018 the population of beef cattle was 111576 heads, increased to 121035 heads in 2019, to 128654 heads in 2020, in 2 years there was an increase in the population of 19078 heads (17.9\%).

Feed carrying capacity is the ability of an area to provide/produce feed so that the area can accommodate many livestock populations. Based on data, the area of planted area for food crops is 233973 ha, the potential for agricultural waste (food crops) consisting of rice straw, field rice straw, corn straw, cassava shoots, peanut straw, soybean straw, green bean straw, and sweet potato tendrils based on the available count of total dry matter (BK) 622863.85 tons/year which can be sufficient for feed 273065.12 ST [12].

\subsection{Cattle population of North Sulawesi}

Beef cattle in North Sulawesi is spread in 15 districts/cities but the population is concentrated in some districts that have a large area of rice fields and dry land. The maintenance of cattle has become a part of the daily life of some people in North Sulawesi, especially those living in rural areas trying to farm. The role of cattle for farming communities is as labor in processing land and as labor to evacuate crops, other functions in the cultivation of livestock as savings that can be cashed at any time (Ready to cash).

The livestock population is a portrait of the performance of livestock development in a region, livestock population density describes the suitability of the livestock with the local 
agroecosystem, the acceptance and interest of the community to the livestock. The description of the cattle population in North Sulawesi province is listed in Table 1.

Table 1. Beef cattle population in North Sulawesi by district/city in 2018.

\begin{tabular}{|l|c|}
\hline \multicolumn{1}{|c|}{ Regency/city } & Beef cattle \\
\hline Bolaang Mongondow & 25310 \\
\hline Minahasa & 25155 \\
\hline Kep. Sangihe & 1877 \\
\hline Kep. Talaud & 1672 \\
\hline Minahasa Selatan & 18046 \\
\hline Minahasa Utara & 16954 \\
\hline Bolaang Mongondow Utara & 17478 \\
\hline Kep. Sitaro & 39 \\
\hline Minahasa Tenggara & 4556 \\
\hline Bolaang Mongondow Selatan & 5541 \\
\hline Bolaang Mongondow Timur & 5018 \\
\hline Manado & 3017 \\
\hline Bitung & 2830 \\
\hline Tomohon Total & 3637 \\
\hline Kota Kotamobagu & 1985 \\
\hline & $\mathbf{1 3 3 1 1 5}$ \\
\hline
\end{tabular}

Source: [13]

The number of beef cattle in North Sulawesi Province in 2018 as many as 133115 heads spread across 15 districts/cities. The largest population in Bolaang Mongondow County is 25,310 (19.01\%); Minahasa Regency 25155 (18.9\%); Regency of South Minahasa 18046 (13.55 \%); North Bolaang Mongondow County 17478 (13.13\%); North Minahasa Regency 16954 (12.73 \%); South Bolaang Mongondow Regency 5541 (4.16 \%); Bolaang Mongondow Timur District 5018 (3.79\%); Regency of Southeast Minahasa 4556 head (3.42\%); Tomohon City 3637 (2.73 \%); Manado City 3017 (2.26 \%); Bitung City 2830 (2.12\%); Kotamobagu 1985 (1.49\%); Regency of Sangihe Islands 1877 (1.41\%); Talaud Islands Regency 1672 (1.26\%) and Sitaro Islands Regency 39 tails (0.03\%).

Based on the existing data, it is illustrated that the population of beef cattle in North Sulawesi Province is concentrated in regencies areas that have intensive farming, especially food crops both in rice fields and dry land. The development of beef cattle in North Sulawesi in the future should consider agroecosystem conditions, availability of feed resources, water, and livestock resources as well as other supporting facilities such as capital and accessibility and markets.

\subsection{Achievement of artificial insemination, pregnant, and birth}

Breeding efforts to produce livestock seedlings with high production propertis. The cattle breeding business is a prospective business, due to the increasing demand for meat and processed [14]. Artificial Insemination (AI) is attempted to obtain a large number of quality off spring, uniform in a certain time and there are savings in the cost of maintenance of males. $\mathrm{AI}$ is also beneficial in the prevention of infectious venereal diseases.

To increase the population of slaughtered livestock, the government has conducted various reproductive biotechnology programs such as Artificial Insemination (AI). The application of Artificial Insemination can increase livestock productivity in both quality and quantity [15]. Artificial Achievement Insemination (AI), gestation and birth. Artificial Insemination Application in North Sulawesi province in 2020 is listed in Table 2. 
Table 2. Achievement of artificial insemination, gardening and birth figures of North Sulawesi 2020

\begin{tabular}{lccc}
\hline \multicolumn{1}{c}{ Moon } & $\begin{array}{c}\text { Artificial } \\
\text { insemination }\end{array}$ & Gestation & Birth \\
\hline January & 219 & 55 & 156 \\
February & 877 & 185 & 201 \\
March & 824 & 205 & 452 \\
April & 965 & 608 & 390 \\
May & 717 & 389 & 793 \\
June & 934 & 564 & 578 \\
July & 1417 & 1599 & 1343 \\
August & 1362 & 1619 & 1034 \\
September & 1381 & 1293 & 1041 \\
October & 1285 & 1005 & 1264 \\
November & 2201 & 1810 & 587 \\
December & 1500 & 1808 & 299 \\
\hline Total & 13682 & 11140 & 8138 \\
\hline
\end{tabular}

Source: WAG Upsus Siwab Sulut Data

In Table 2 the artificial insemination application with 13682 acceptors produced a yield of 11140 , and the mothers who gave birth from January to December 2020 were 8138 heads. The birth rate translated as the addition of cattle populations. The success of artificial insemination application is very determined at the time of insemination, and the time of lust needed to be handled appropriately [16].

\subsection{Service per conception}

Reproductive efficiency is a measure of the successful reproduction of a normal group of broods in natural mating or Artificial Insemination [17]. Reproductive performance is determined based on S/C, CvR, and CR [18]. S/C is one measure of the number of insemination services needed until the event of gestation [19]. Reproductive performance of beef cattle artificial insemination aseptors is shown in Table 3.

Table 3. Reproduction performance of beef cattle artificial insemination aseptors in North Sulawesi

\begin{tabular}{|l|c|c|}
\hline \multicolumn{1}{|c|}{ Parameters } & Value & Normal value \\
\hline Sevice Per Conception $(\mathrm{S} / \mathrm{C})$ & 1.22 & $1.65-2.00$ \\
\hline Calving Rate $(\mathrm{CvR})$ & $78 \%$ & $55-65 \%$ \\
\hline Conseption Rate $(\mathrm{CR})$ & $81.4 \%$ & $65-75 \%$ \\
\hline
\end{tabular}

Source: Data processed

The $\mathrm{S} / \mathrm{C}$ value indicated the fertility rate of the mother cow in one group, the smaller the $\mathrm{S} / \mathrm{C}$ value, the better the fertility of the cow mother. Hariadi [20] stated that the number S/C is considered good when showing the number up to 1.65 . The data analysis results showed the $\mathrm{S} / \mathrm{C}$ number 1.22. It was indicated that the insurance of inseminated cow parent was relatively good. Service Per conception $(S / C)$ is a number that shows how many times to perform IB services to make the cow pregnant. The value of $\mathrm{S} / \mathrm{C}$ indicates the level of fertility of a group of cows. The smaller the S/C value indicates the fertility level of a group of cows in one area is more fertile, and vice versa, the larger $\mathrm{S} / \mathrm{C}$ value shows the cows are less fertile. 


\subsection{Calving rate (CvR)}

Calving rate $(\mathrm{CvR})$ is a number that describes the percentage of calves born from artificial insemination. The results of the analysis were based on CvR value of $73 \%$ (Table 3). It gave an overview of the birth rate of artificially inseminated beef cattle in North Sulawesi exceeded the normal figure and was well-category compared to the normal value of CvR 55 - $65 \%$ [20]. The calving rate is determined by the fertility of the mother during insemination and the ability to care for the fetus in her womb [21]. Parent fertility is associated with good feed intake quality, quantity, and continuity.

\subsection{Conception rate (CR)}

Conception Rate (CR) is one way of measuring the reproductive efficiency of a single beef cattle population. Conception rate is the percentage of pregnant heifers from the first insemination [22]. Ideal conception rate in one beef cattle population of $65-75 \%$. The CR value obtained in this study is $81.4 \%$, this figure is higher than the normal CR value. Factors that determine the high or low value of $\mathrm{CR}$ are inseminator skills, completeness of insemination tools and supporting materials, timeliness of insemination application, skills of farmers detecting estrus, and knowledge in terms of feed management and livestock health [23].

\section{Conclusion}

Artificial insemination applications in Nort Sulawesi in 2020 was done successfully. It was indicated by $\mathrm{S} / \mathrm{C}$ value of 1.22 , CvR $73 \%$, CR of $81.4 \%$, and an increase in the population of 8138 heads. The Upsus Siwab program has entered its 4th year and has resulted in good learning and communication between farmers and inseminators. Breeders have increased knowledge and skills regarding the detection of oestrus so that it is reported as soon as possible so that inseminators with available insemination infrastructure can determine the right time to carry out IB services. This is indicated by the CR $81.4 \%$ which is higher than the normal value of CR $65-75 \%$.

\section{References}

1. Suprianto and D. Djuliansah, Pulpit Agibisnis 1, 3:211-226 (2016).

2. Yusriani. Y and Rahmah. F.F. 2020. J. Agriflora 4, 1:34-42 (2020).

3. Ilham N. Saptana. Purwanto A. Supriyatna. Nurasa T, The study of the development of the livestock industry supports the increase in meat production. Center for SocioEconomic and Agricultural Policy. Balitbangtan. Ministry. Bogor (2015)

4. Nuryadi and Wahjuningsi.S. 2011. A. Tropical Livestock. 12, 1: 76-81 (2011)

5. Asmairiencen S. Yusriani Y. and S.Y Hayati, Potential development of artificial insemination (IB) to increase the population in support of the SIWAB program in Gayo Lues District of Aceh Province. Proceedings of Semnas VI HIPTI. ISBN 978-60250946-0-6 (2017)

6. Yuwantoro. Mudawamah and Suryanto, Journal of Rekasatwa Ranch. 2, 1: 34-42 (2019)

7. Said, Syahruddin, Improving the Population and Genetic Quality of Indonesian Livestock Through the Application of Reproductive Biotechnology in Order to Promote Acceleration of National Meat and Milk Self-Sufficiency. Bogor. Center for Biotechnology Research - LIPI (2014) 
8. Rachmawati A. Ismaya. Budi Prasetyo Widyaobroto. Sigit Bintara and Trinil Susilawati, Journal of Animal Husbandry. 28, 3: 47-58 (2018)

9. Yusriani. Y and Rahma. F.F., J. Agriflora 4(1):34-42 (2020)

10. Rahmat, D, Mulliadi, D, Winaryanto, D.S. Rangga,. and, Alim, S. Sms Gateway Application In Strengthening Ib Beef Recording Systems In West. Journal of Animal Science (JANHUS) 1, 2: 1-6 (2017)

11. Puslitbangnak, Measurable parameters of escort and assistance of crop-livestock integration technology. Center for Livestock Research and Development. Agricultural Research and Development Agency. Ministry of Agriculture (2016)

12. Tanuwiria, U. H. (2007), JournalAgroland. 14, 1: 56-60 (2007)

13. BPS, North Sulawesi in 2015 Figures (2015)

14. Kastalani. Torang H. Kurniawan A., Journal of Tropical Animal Sciences 8, 2:82-88 (2019)

15. Kastalani. Torang H. Kurniawan A., Journal of Tropical Animal Sciences 8, 2:82-88 (2019)

16. Ramli M. Siregar T.N. Thasmi C.N. Dasrul. Sriwahyu and Syayuti A. 2016. The relationship between estrus intensity and estradiol concentration in Aceh cows at the time of insemination. Journal of MediaVeterinaria 10, 1:34-42 (2016)

17. Feradis, Reproductive Biotechnology in Livestock. The alphabet. Bandung (20100

18. Susilo T., The efficiency of reproduction of artificial insemination program for local cows in wetland and dry areas in Magelang district of Central Java province [Thesis]. Faculty of Animal Husbandry. Diponegoro University (2005)

19. Masruroh L.S. Lokapirnasari W.P and Restiadi. T.I., Avozoa. 8, 1: 71-75 (2019)

20. Hariadi, M. S. Hardjopranyoto. Wurlina H.A. Hermadi B. Utomo. Rimayanti I.N. Triana and H. Ratnani. 2011. The Science of Animal Husbandry (Airlangga University Press, Surabaya, 2011)

21. Toelihere M. R., Artificial Insemination in Livestock (Angkasa Publishers, Bandung, 1977)

22. Jindal S.K. and M.C. Sharma, Biotechnology in Animal Health and Production. (New India Publishing Agency. Pitam Pura, New Delhi, 2010)

23. Hardijanto S. Susilowati T. Hernawati T. Sardjito and T.W. Suprayogi. 2010. Artificial Insemination Teaching Book (Airlangga University Press, Surabaya, 2010) 